slides previously fixed in cold 10 per cent formal-methanol showed only very weak staining in some neutrophils and in some monocytes. The use of 60 per cent citrate buffered acetone as a fixative for acetyl esterase and cold 10 per cent formal-methanol as a fixative for the enzyme-hydrolysing chloroacetates was helpful in distinguishing immature myeloid elements from immature monocytes, as was pointed out by Moloney?

The fixative solution is used and stored at room temperature and is prepared by adding $300 \mathrm{ml}$. of absolute acetone, while stirring, to a mixture of $32 \mathrm{ml}$. of $0.03 \mathrm{M}$ sodium citrate (dihydrate) and $168 \mathrm{ml}$. of $0.03 \mathrm{M}$ citric acid (monohydrate).

Previously, 60 per cent aqueous acetone was suggested as a fixative for succinic dehydrogenase by Quaglino and Hayhoe $^{8}$. Optimal cell preservation is not obtained with the aqueous solution and in some cases less activity was observed as compared with that obtained on smears fixed with the acid-buffered acetone mixture.

The availability of a fixative capable of simultaneously preserving enzyme activity and cell morphology should prove of value to those utilizing techniques for the cytochemical localization of enzymes in smears.

L. S. KAPLOW*

M. S. Burstone

Diagnostic Research Branch,

National Cancer Institute,

National Institutes of Health, Bethesda, Maryland.

*Post-doctoral Fellow of National Heart Institute, U.S. Public Health Service. Present address: Department of Pathology, Medical College of Virginia, hichmond, Virginia.

'Gomori, G., Microscopic Histochemistry Principles and Practice, 140 (Univ. Chicago Press, 1952).

${ }^{2}$ Burstone, M. S., J. Histochem. and Cytochem., 9, 146 (1961).

${ }^{3}$ Burstone, M. S., Amer. Med. Assoc. Arch. Pathol., 63, 164 (1957).

4 Moloney, W. C., McPherson, K., and Fliegelman, L., J. Histochem. and Cytochem., 8,200 (1960).

soffler, H., Klin. Wochschr., 39, 1220 (1961).

'Kaplow, L. S., Blood, 10, 1023 (1955).

"Moloney, W. C., Proc. Eighth Congr. European Soc. Hoematol., 1, No. 9 (1961).

${ }^{8}$ Quaglino, D., and Hayhoe, F. G. J., Nature, 187, 85 (1960).

\section{Preparation of Thick Sections for Cytochemistry and Electron Microscopy by a Non-freezing Technique}

At present thick $(\sim 50 \mu)$ frozen sections of fixed tissues are commonly utilized for cytochemistry and electron microscopy ${ }^{1-3}$ despite the fact that freezing and thawing are known to cause disruption of fine structure and loss of enzymatic activity even in fixed tissues ${ }^{3,4}$. These disadvantages have been tolerated since use of sections not exceeding $50 \mu$ is necessary to ensure even penetration of incubation media ${ }^{1,2}$, and no alternative sectioning method has been available.

We have recently developed a non-freezing technique for preparing such thick sections that results in greatly improved preservation of cellular structuro while retaining higher levels of enzymo activity than the usual frozen section procedures. Sections are cut with a McIlwain mechanical tissue chopper (manufactured by GomshallSurry), an instrument ordinarily used to prepare somewhat thicker slices of fresh tissue for metabolic investigations ${ }^{5}$.

We have found the following technique satisfactory for cutting sections of about $50 \mu$ : A piece of fixed tissue (about $1.2 \times 1.0 \times 5-10 \mathrm{~mm}$ ) is placed in the centre of a pad composed of 6-7 pieces of $5.5 \mathrm{~cm}$ filter paper (Whatman No. 1) held together with 'Cellophane' tape. The tissue is covered with a few drops of liquid 7 per cont agar (or a low melting point paraffin) dripped on to its surface with a warmed dropper pipette. (The agar solution is liquefied by heating in a water bath and subsequently stored at $42^{\circ} \mathrm{C}$ during use.) The pad containing the tissue is placed in the refrigerator for several minutes until the agar hardens. It is then secured to the circular metal table of the chopper with a few drops of paraffin placed between the bottom piece of filter paper and the metal table. The chopper is set to cut at $0.052 \mathrm{~mm}$ and a double-edged razor blade (Schick stainless steel) is mounted in the holder. The speed control is set at about 200 strokes per minute, and the chopper arm is positioned so that it barely contacts the left edge of the specimen. The instrument is switched on and allowed to remain so until the specimen has been completely traversed by the chopping action of the machine, which passes through the tissue from left to right. The sections are then removed from the agar and placed in the desired solution, where they readily separate. The entire operation takes less than $10 \mathrm{~min}$.

We have utilized the foregoing technique to prepare sections of a number of tissues (for example, pituitary, liver, intestine, kidney, pancreas, skin) fixed in 2-3 per cent glutaraldehyde (buffered at $p \mathrm{H} \quad 7.2$ with $0.1 \mathrm{M}$ eaccodylate buffer ${ }^{3}$ ) and stored for variable periods in buffer. The sections have afterwards been treated by several histochemical procedures, 'post-fixed' in osmium and embedded in 'Araldite'. When examined in the electron microscope these tissues have consistently showed a substantial improvement in general morphology, intensity of histochemical reaction and sharpness of localization of enzyme activity over those prepared by frozen section techniques. Improved enzyme survival was demonstrated by the fact that shorter incubation times could be utilized for the non-frozen than for frozen sections to achieve the same intensity of reaction. Even more notable is the fact that carefully prepared chopper sections appeared nearly free of the gross defects (tears, gaps, large membrane discontinuities, retraction between cells), which in our experience invariably characterize to some extent the frozen sections.

This investigation was supported by grants $A-6387$ and 2G-349, U.S. Public Health Service.

\section{R. E. SmIth \\ M. G. FARQUHAR}

Department of Pathology,

University of California School of Medicine, San Francisco 22.

1 Novikoff, A. B., Essner, E., Goldfischer, S., and Heus, M., in The Interpretation of Ultrastructure (Academic Press, New York and London, Holt, S. J., and Hicks, R. M., J. Biophys. Biochem. Cytol., 11, 31 (1961).

${ }^{3}$ Sabrtini, D. D., Bensch, K., and Barrnett, R. F., J. Cell Biol., 17, 19 (1963).

- Novikoff, A. B., Burnett, F., and Glickman, M., J. Histochem. Cytochem., 4, 416 (1956)

${ }^{5}$ Mellwain, H., and Buddin, H. L., Biochem. J., 53, 412 (1953).

\section{PATHOLOGY}

\section{Electrical Charge Density of Spleen Cells sensitized against $L$-strain Fibroblasts}

It has previously been shown that homologous and heterologous spleen cells, sensitized against $L$-strain fibroblasts, have a marked cytopathic effect on the fibroblasts in vitro ${ }^{1,2}$. It was thought useful to examine the electrical surface charge density of these sensitized spleen cells in view of the possible changes which occur at the cell surface during the process of sensitization. This communication presents such results obtained by cell electrophoresis.

Mice or guinea pigs were sensitized as described by Taylor and Culling ${ }^{1}$ : briefly, this involved two intraperitoneal and one intrasplenic injection of $L$-strain fibroblasts over a period of nine weeks. Five days after the intrasplenic injection the spleen was removed and weighed. Polyvinylpyrrolidone brush smears of the spleen were stained by the acridine orange and Wright's techniques for differential cell counts (lymphocytes, pyroninophilic proplasma and plasma cells and occasional granulocytes). The spleen was then macerated and shaken with glass beads in Medium 199 to obtain a homogeneous cell sus- 